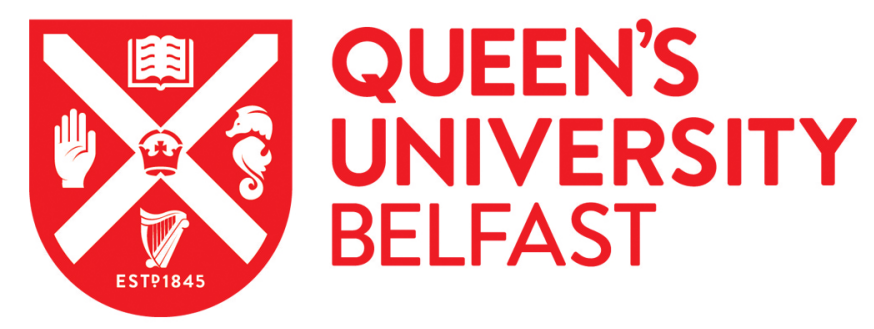

\title{
Raiffeisenism abroad: why did German cooperative banking fail in Ireland but prosper in the Netherlands?
}

Colvin, C. L., \& McLaughlin, E. (2014). Raiffeisenism abroad: why did German cooperative banking fail in Ireland but prosper in the Netherlands? Economic History Review, 67(2), 492-516. https://doi.org/10.1111/14680289.12030

\section{Published in:}

Economic History Review

\section{Document Version:}

Peer reviewed version

Queen's University Belfast - Research Portal:

Link to publication record in Queen's University Belfast Research Portal

\section{Publisher rights}

(C) Economic History Society 2013.

This is the peer reviewed version of this article, which has been published in final form at DOI: 10.1111/1468-0289.12030. This article may be used for non-commercial purposes in accordance with Wiley Terms and Conditions for Self-Archiving.

\section{General rights}

Copyright for the publications made accessible via the Queen's University Belfast Research Portal is retained by the author(s) and / or other copyright owners and it is a condition of accessing these publications that users recognise and abide by the legal requirements associated with these rights.

Take down policy

The Research Portal is Queen's institutional repository that provides access to Queen's research output. Every effort has been made to ensure that content in the Research Portal does not infringe any person's rights, or applicable UK laws. If you discover content in the Research Portal that you believe breaches copyright or violates any law, please contact openaccess@qub.ac.uk. 


\title{
Raiffeisenism abroad: why did German cooperative banking fail in Ireland but prosper in the Netherlands?
}

\begin{abstract}
Why did imitations of Raiffeisen's rural cooperative savings and loans associations work well in some European countries, but fail in others? This article considers the example of Raiffeisenism in Ireland and in the Netherlands. Raiffeisen banks arrived in both places at the same time, but had drastically different fates. In Ireland they were almost wiped out by the early 1920s, while in the Netherlands they proved to be a long-lasting institutional transplant. Raiffeisen banks were successful in the Netherlands because they operated in a niche market with few competitors, while rural financial markets in Ireland were unsegmented and populated by long-established incumbents, leaving little room for new players, whatever their institutional advantages. Dutch Raiffeisen banks were largely selffinancing, closely integrated into the wider rural economy and able to take advantage of economic and religious divisions in rural society. Their Irish counterparts were not.
\end{abstract}

$\mathrm{R}$ aiffeisen banks were a type of financial intermediary designed in Germany in the mid-nineteenth century to provide small-scale financial services to customers in rural areas. Their organizational form was then novel; they were owned and operated cooperatively by the people who borrowed from them. European rural reformers of the late-nineteenth and early-twentieth centuries adopted the Raiffeisen cooperative banking model as a means of empowering and improving the lives of farmers. ${ }^{1}$ However, outside Germany their success was variable, despite the efforts of their idealistic early propagators; Raiffeisenism prospered in Italy and the Netherlands, failed in Belgium, Ireland and Spain, and never even got off the ground in Denmark. This article explores the reasons for this variation in performance by comparing their fate in Ireland and the Netherlands. The striking features of Raiffeisenism in these countries, on which the comparison focuses, are in: (1) their reliance on savings as a source of funding; (2) the levels of integration within and between cooperative enterprises; and (3) their treatment of socioreligious and socioeconomic divisions.

The literature on early cooperative banking in Europe includes the ground-breaking work of Guinnane and his co-authors, ${ }^{2}$ who seek to explain the performance of Raiffeisen cooperatives, principally in Germany, at the turn of the century. Guinnane's major contribution has been to argue that they were successful because they could overcome by mutuality the information asymmetries and enforcement problems that prevented conventional banks from lending to the rural unbanked and

\footnotetext{
${ }^{1}$ Parallels between cooperative banks in the past and microfinance institutions today have been drawn by various scholars (see Bátiz-Lazo and Billings, 'New perspectives', for a review of the recent literature).

${ }^{2}$ Banerjee, Besley, and Guinnane, 'Thy neighbor's keeper'; Ghatak and Guinnane, 'The economics'; Guinnane, 'Cooperatives as information machines'; Guinnane, 'Delegated monitors'; Guinnane, 'A “friend and advisor"'.
} 
underbanked. His research on Raiffeisenism in Ireland was the first to apply information economics to aspects of the island's economic history. ${ }^{3}$ However, his work largely discounts the possibility that factors unrelated to these banks' institutional design account for their dismal histories. By complementing Guinnane's institutional approach with the functional perspective popularised by Merton, ${ }^{4}$ and by comparing the Irish case with the contemporaneous and ultimately more successful imitation of Raiffeisen banks in the Netherlands, this article reconsiders Guinnane's arguments. Starting not with the institutional structure of financial intermediaries, but with the economic functions needed of them, Merton's functional perspective asks how these are best provided. Rather than looking at a single case of Raiffeisenism abroad, the comparative approach contrasts largely similar societies which yet differ in the factors under review, enabling more robust inferences to be drawn. Guinnane's central thesis is that in Ireland's case 'cooperatives did potentially fill an important gap in rural credit markets', ${ }^{5}$ but the methodological approach of the present essay concludes that they did not; Irish credit cooperatives disappeared because rural savers and lenders were adequately served by pre-existing functionally-equivalent competitors, principally the joint stock banks (JSBs) and the Post Office Savings Bank (POSB).

Existing accounts of Raiffeisenism abroad motivate this article's choice of methodology and indicate where its contribution lies. Histories of the experience of Raiffeisenism in Western Europe rely on country-specific studies. ${ }^{6}$ Recent essays on Raiffeisenism in Eastern Europe consider several at once, encouraging comparison. ${ }^{7}$ Despite this move, the restricted view of previous studies means that they cannot distinguish between factors peculiar to given cases and universal analyses of cooperative performance. Parallels are drawn only with Raiffeisenism in Germany, but are inadequate because they assume that the apparently successful German institution evolved by definition as superior. Such assumptions have blinded scholars to other institutions that were functionally equivalent to Raiffeisen's banks. Section I's comparison of the origins and early history of Dutch and Irish

\footnotetext{
${ }^{3}$ Guinnane, 'A failed institutional transplant'.

${ }^{4}$ Merton, 'A functional perspective'; Merton and Bodie, 'A conceptual framework'.

${ }^{5}$ Guinnane, 'A failed institutional transplant', p. 39.

${ }^{6}$ Belgium's cooperative spaar- en leengilden (savings and loans guilds) failed in the Great Depression after lending excess deposits to risky large non-agricultural business ventures (Van Molle, 'Savings and loans'); Denmark's sognesparekasser (parish savings banks) left little room to introduce cooperatively-owned rural banks (Henriksen and Guinnane, 'Why Danish credit co-operatives'); Italy's casse rurali (rural banks) succeeded by exploiting cultural and social factors (Galassi, 'Measuring social capital'); and Spain's cajas rurales (rural savings banks) were very unsuccessful, largely for political reasons (Garrido, 'Why did most cooperatives fail?').

${ }^{7}$ Lorenz (ed.), Cooperatives in ethnic conflicts, suggests that Raiffeisen banks worked in Eastern Europe by embedding themselves in the ethnic and political movements of minority populations.
} 
Raiffeisenism suggests that the polities form a matched pair, in their broadly similar agricultural sectors and religious heterogeneity. These commonalities enable the present study to better identify the necessary and sufficient conditions for the long-run success of Europe's early cooperative banks.

Three findings emerge from section II, which compares the function and design of Raiffeisenism in Ireland and the Netherlands. The first, discussed in section III, is that savings rates were a key success factor of the Raiffeisen model. Unlike their German progenitors, both Dutch and Irish cooperators chose to adopt institutional names with no reference to saving. In practice, however, Dutch cooperatives retained an emphasis on savings; to finance their loan books boerenleenbanken (farmers' lending banks) relied on members' deposits rather than external borrowing. By contrast, concessional state loans were the main source of finance for Ireland's Raiffeisen banks, known locally as agricultural banks or agricultural credit societies.

The second, discussed in section IV, is that the close integration, both horizontal and vertical, of different cooperative enterprises was an important determinant of success. In the Netherlands, Raiffeisen banks enjoyed strong federated apex institutions and overlapped in membership and management with other local cooperative enterprises which they financed. By contrast, cooperatives in Ireland showed few signs of integration.

The third finding, discussed in sections V and VI, is that socioreligious and socioeconomic division led in the Netherlands to a dichotomous cooperative banking structure for Catholics and Protestants, with strong independent cooperative networks, attracting all strata of society. However, though cooperatives were promoted as compatible with Roman Catholicism, the majority religion in Ireland, the political economy of Irish rural society seems to have discouraged them from taking root.

Together, these three findings suggest not only that Dutch and Irish forms of cooperative banking had important institutional differences, but also that they differed crucially in the functions they performed (section VII). Dutch Raiffeisen banks successfully exploited and dominated a niche market where few competitors could offer equivalent services, while their Irish counterparts faced stiff competition from incumbents that performed similar economic functions. Dutch Raiffeisen banks used their institutional characteristics to gain a central position in Dutch rural society, while their Irish cousins gained little from being cooperative.

\section{I}

The historical context of this article is the "Grain Invasion": the late nineteenth century integration of global agricultural markets and its effect on prices. ${ }^{8}$ While France, Italy and the German Empire

\footnotetext{
${ }^{8}$ O'Rourke, 'The European grain invasion'. In British historiography, this has traditionally been termed the Great Depression (Capie and Wood, 'Great Depression'), and in the Dutch the Grote Landbouwcrisis (the Great Agricultural Crisis) (Bieleman, Boeren in Nederland).
} 
attempted to stem the tide with protectionist barriers, Denmark, the Netherlands and the UK (of which Ireland was part) did not. ${ }^{9}$ Dutch and Irish farmers had to rely on land-saving technologies, such as chemical fertilizers, concentrated animal feeds, superior breeds of seed and livestock, and innovative methods of agricultural organization, such as cooperative enterprises. ${ }^{10}$

The diffusion of German-designed credit cooperatives abroad was particularly important in the wider history of agricultural cooperation in Europe. Broadly, cooperatives of three kinds formed in German states: Schulze-Delitzsch, Raiffeisen and Haas. Each strand had a distinct interpretation of its economic function and institutional structure. By far the most frequent to be copied abroad was the second. Friedrich Wilhelm Raiffeisen (1818-1888), whose name passed to this type, established the first of his cooperative banks in Rhenish Prussia in the 1840s, ${ }^{11}$ but it took almost 40 years for them to 'perceptibly multiply'. ${ }^{12}$ Data collected by Prinz show that the number of Raiffeisen societies grew from 63 in 1875 to 121 in 1881, and 713 in $1892 .{ }^{13}$ 1894, the year in which the first Raiffeisen society was established in the southwest of Ireland, saw 980 German Raiffeisen banks; the number had reached 2,014 in 1897, a year after the first Dutch Raiffeisen bank was opened, near the German border.

The Irish Agricultural Organisation Society (IAOS), a cooperative advocacy body founded in Dublin, organized cooperative banks across the Irish countryside wherever it determined credit was needed, partly to combat "gombeenism", a pejorative term for usurious moneylending. ${ }^{14}$ The traditional argument put forward in the Dutch historiography is that boerenleenbanken were created in response to an unfulfilled demand for credit in rural areas - a view Bieleman has held as recently as 2008. ${ }^{15}$ The root of this view lies with the Dutch government's agricultural inquiries of the late

\footnotetext{
${ }^{9}$ Webb, 'Agricultural protection'; Van Zanden, 'The first green revolution'; Henriksen, Lampe and Sharp, 'The strange birth'.

${ }^{10}$ Additionally, in the Netherlands, the amount of available land was increased through reclamation works (Knibbe, Agriculture in the Netherlands, p. 48); and in Ireland, farmers revived their tradition of mass emigration (Hobsbawm, The age of empire, p. 36).

${ }^{11}$ Digby, The world co-operative movement, p. 76.

${ }^{12}$ Wolff, Peoples' banks, p. 71. Birchall, The international co-operative movement, dates the first such mutual society to 1862, while Guinnane, 'A "friend and advisor"', to 1864.

${ }^{13}$ M. Prinz, 'German rural cooperatives, Friedrich-Wilhelm Raiffeisen and the organization of trust', XIIth Meeting of the International Economic History Association, Buenos Aires (2002).

${ }^{14}$ Report from the S. C. (P.P. 1898).

${ }^{15}$ Bieleman, Boeren in Nederland. This argument recurs in corporate histories of the Dutch rural cooperative banking movement: Campen et al., Landbouw en landbouwcrediet; Weststrate, Gedenkboek; Sluyterman et al., Het coöperatieve alternatief.
} 
nineteenth century, ${ }^{16}$ and with propaganda from Dutch cooperative banks at the time, such as Van der Marck's 1924 pamphlet. $^{17}$

By the end of the 1910s, a dense network of boerenleenbanken served the whole Dutch countryside; some 18 per cent of the population ${ }^{18}$ deposited about 32 per cent of the nation's savings with them. ${ }^{19}$ In Ireland, their growth was not sustained, but the Danish-inspired cooperative creameries introduced simultaneously met greater success. ${ }^{20}$ Figure 1 plots the number of Raiffeisen banks in both polities relative to their populations and shows that Ireland's experiment with cooperative banking failed long before the Irish War of Independence.

\title{
[Insert figure 1]
}

\section{II}

Raiffeisenism was not unopposed in Germany; Guinnane demonstrates that different competing institutions, some considerably more successful than others, operated simultaniously. ${ }^{21}$ Nonetheless, Raiffeisen's banking model was the one to be introduced to the Dutch and Irish countryside. ${ }^{22}$ Below is a contemporary outline of its principles: ${ }^{23}$

\begin{abstract}
Everyone who knows anything at all of agricultural co-operation is familiar with the main features of the system, namely, unlimited liability, an area restricted to a village or two, small shares, limited dividends or no dividends at all, indivisible reserve, loans to members only, low rates of interest and honorary management controlled by the general assembly of members, each of whom has one vote and no more. In detail one country or province may vary from another, but the ground principles are everywhere the same, and wherever they are found and however they appear to be derived, their ultimate origin is Germany and their sponsor Raiffeisen.
\end{abstract}

The institutional attributes of Raiffeisen cooperatives in Ireland and the Netherlands compared with Germany's (table 1) reveal how far the three cases reflect this succinct description. The

\footnotetext{
${ }^{16}$ Nationaal Archief, The Hague, Landbouwcommissie, 1886-1891, access no. 2.11.25, inv. no. 6.

${ }^{17}$ Van der Marck, Boerenleenbanken. This pamphlet, and previous editions before it, was widely distributed among local Raiffeisen banks. Its author, Van der Marck, was the geestelijke adviseur (spiritual advisor) to the leading Catholic-aligned Raiffeisen network.

${ }^{18}$ Calculated using the 1920 census (http://www.volkstellingen.nl/) and the annual reports of the three cooperative central banks (CCB, Jaarverslag 1919; CCCB, Jaarverslag 1919; CCRB, Jaarverslag 1919). If by 1920 the Netherlands' rural population represent 55 per cent of their total (United Nations, Growth, p. 105), then perhaps all rural Dutch households had a Raiffeisen account.

${ }^{19}$ Sluyterman et al., Het coöperatieve alternatief, p. 40.

${ }^{20}$ Breathnach, 'The diffusion'.

${ }^{21}$ Guinnane, “A “friend and advisor", p. 263.

${ }^{22}$ The reason why Raiffeisen's model was more successfully marketed abroad than any of these others is an unresolved question.

${ }^{23}$ Darling, Some aspects, p. 18.
} 
regulatory regime of all three polities let cooperatives choose among liability options, corporate governance structures and business restrictions - albeit with various differences in the enterprise forms used. The liability structure was always unlimited, although the legal regime of all three allowed otherwise. Raiffeisen cooperatives' banking activities were conducted at a local level in all three places, the area restriction outlined by Darling; but in the Netherlands, different Raiffeisen banks often competed within the same locality. Moreover, none of the polities had banks with shareholdings; membership usually required a signature on a registry and some nominal deposit. Loans were always granted exclusively to members; since membership was not a pre-requisite for savings, many depositors joined only when they needed a loan.

\section{[Insert table 1]}

At least two cosignatories were normally required to secure loans in all three polities. ${ }^{24}$ Loan terms in Germany and the Netherlands varied in length and ceilings were not mandatory, but a series of checks and balances prevented abuse; for example, in the Netherlands large loans required authorisation from a central apex institution. Dutch cooperatives appear to have adjusted loan terms to clients' risk by varying the size and period of the loan, not the interest rate. ${ }^{25}$ Ireland, by contrast, operated under a legislatively imposed loan ceiling of $£ 50$ and the IAOS encouraged cooperatives to restrict themselves to short-term lending. ${ }^{26}$ All three governments gave support and subsidy: German Raiffeisen cooperatives received subsidized loans; in the Netherlands subsidization came in the form of small start-up grants; and in Ireland, state bodies offered loans at concessional rates of interest.

In all three polities, cooperative banks were unit independent and affiliated to various apex institutions. In Germany these institutions were regional, while in the Netherlands they were theoretically national and apolitical, but in practice divided to reflect the strong socioreligious division of Dutch society - a phenomenon known as verzuiling (pillarization) ${ }^{27}$ In both Germany and the Netherlands, apex institutions, acting as clearinghouses and auditors, were cooperatively owned by member cooperatives (federated "cooperatives' cooperatives"): distinct institutions in Germany, but united in the Netherlands in organizations called centrale banken (central banks). Ireland, by contrast, did not develop such institutions. Its apex, the IAOS, helped establish individual cooperatives (banks, creameries and stores) and provided auditing services, but was unfederated and not a clearinghouse. Cooperative integration, between cooperative banks and also among other cooperative enterprises,

\footnotetext{
${ }^{24}$ Sowers, 'The role of social networks', finds that loan cosignatories were often borrowers too, causing dense interconnected networks of financial ties between Raiffeisen cooperators.

${ }^{25}$ E.g., the boerenleenbank in Capelle, Noord-Brabant, always adopted an interest rate very close to that at which it could borrow money, managing risk instead by altering the loan principal (Archief Rabobank Langstraat (henceforth ARL), Capelle NB, Bestuursnotulen Boerenleenbank Capelle).

${ }^{26}$ Anderson, With Plunkett, p. 252.

${ }^{27}$ Van Eijnatten and Van Lieburg, Nederlandse religiegeschiedenis.
} 
distinguished Raiffeisenism in Germany and the Netherlands from Ireland, where little integration appeared.

Comparing the agricultural sectors of these polities reveals some similarities but noticeable differences (tables 2 and 3). Regarding the output per hectare of arable land, Ireland resembled the Netherlands in wheat, barley, oats and potatoes and both showed higher output than Germany. Ireland had a higher ratio of cattle and sheep per 1,000 population than the other two. ${ }^{28}$ Over time, a noticeable difference was the Dutch focus on dairy versus livestock production and the rapid expansion of horticulture. ${ }^{29}$ The data suggest that all three had similar farm sizes - mainly small-scale - but that farm ownership differed.$^{30}$ While these data take little account of Irish and Dutch regional specialisation, they suggest overall that Raiffeisenism was introduced to largely comparable agricultural structures and hence that the success or failure of the movement depended more on other factors.

\section{[Insert tables 2 and 3]}

What factors might these be? Possible answers in the Irish case are found in the work of Guinnane: (1) competition in savings markets from the POSB; (2) lack of strong union federations; and (3) prevailing norms in rural Ireland. ${ }^{31}$ (1) Guinnane argues that Raiffeisenism's failure in Ireland and success in Germany cannot be based on the presence or absence of a state-owned savings bank like the POSB. He supports his argument by noting that Germany also had savings banks, municipal rather than national, similar in function to the POSB. But Ireland too had such municipal banks, which dramatically declined in number and scale as the new POSB expanded in the late nineteenth century. How could the POSB enter Ireland in 1863 and outdo these? (2) Guinnane argues that Ireland had no institutional equivalents to the German audit unions and central clearinghouses at the apex. He finds the lack of audit unions more detrimental, since they provided external management and support. Why were such institutional structures not developed in Ireland? (3) Guinnane asserts that one reason for the failure of Irish cooperatives was that the 'norms of Irish society' made cooperative systems difficult to work. ${ }^{32}$ Using a statement from the 1926 banking commission, he suggests that 'rural Irish people did not give "full recognition of the justice of the debt so incurred," and thus resisted efforts to force repayment of loans' ${ }^{33}$ Guinnane's interpretation has implications for the wider history of Irish banking: if the rural Irish resisted attempts to enforce repayments, how were Ireland's other financial institutions able to function?

\footnotetext{
${ }^{28}$ Upper-bound estimates; a greater proportion of Ireland was rural than either Germany or the Netherlands.

${ }^{29}$ Knibbe, Agriculture in the Netherlands.

${ }^{30}$ Mitchell, International historical statistics; Henning, Deutsche wirtschafts- und sozialgeschichte.

${ }^{31}$ Guinnane, 'A failed institutional transplant'.

${ }^{32}$ Ibid., p. 39.

${ }^{33}$ Ibid., p. 57.
} 
The literature on the Dutch success story is dominated by corporate business histories that take an idealistic view of their emergence. ${ }^{34}$ Rommes's forthcoming book on the wider origins of cooperation in the Netherlands breaks this trend, arguing that Dutch rural financial services were already ample when cooperatives entered the market in the late $1890 \mathrm{~s} .{ }^{35} \mathrm{He}$ argues that kassiers, small private cashiers, were good alternative sources of funds and were especially active in the northern Netherlands, precisely where Raiffeisen banks arrived last. However, his implied conclusion that there was therefore little demand for boerenleenbanken appears over-stated and does not explain their exceptional performance during the severe domestic and international financial crises of the 1920s and 1930 s. ${ }^{36}$ In common with other works on Dutch rural cooperation, Rommes focuses more on the market for credit than the market for savings deposits. What happens to his explanation of Raiffeisenism if this focus is reversed? Moreover, are Guinnane's three findings transferable to the Dutch case?

Using insights from the above comparisons as points of departure, this article advances three interrelated explanations for the varying success of Raiffeisenism abroad: (1) how cooperatives were funded; (2) how far they became integrated into the rural economy; and (3) how far they could exploit the religious and economic divisions in rural society.

\section{III}

Rural activists in both Ireland and the Netherlands perceived a need for Raiffeisen banks; but their subsequent economic function in these polities diverged. How does this help explain Dutch success and Irish failure? Contemporaries at the IAOS and in Dutch farmers' unions had the same argument: any problems faced by farmers wanting financial services would be solved by cooperative banks. Their descriptions of market conditions suggest that the financial intermediaries at the time practised either "credit rationing" or "red-lining" ${ }^{37}$ Credit rationing implies that banks might increase their market share and attract more borrowers even by increasing interest rates or collateral requirements, but hesitate to do so due to the high risk of the proposed projects or to some information asymmetry

\footnotetext{
${ }^{34}$ See, e.g., Mooij, De Rabobank.

${ }^{35}$ Rommes, Voor en door boeren?

${ }^{36}$ A succinct history of boerenleenbanken in the interwar period is found in Mooij, 'De brandkast'.

${ }^{37}$ Credit rationing, an equilibrium concept, occurs when borrowers' demand for credit is turned down, even if these borrowers are willing and able to pay both the interest rate and meet the collateral requirements of prevailing loan contracts. Red-lining - a term originally coined to describe the practice of marking a red line on a map to delineate areas where banks would not invest, and later linked to discrimination - occurs when complete categories of borrowers are totally excluded from the credit market because they do not have the necessary future cash flows or collateral to service loans at prevailing prices (Freixas and Rochet, Microeconomics of banking, $\mathrm{p}$. 172).
} 
which makes business performance unverifiable. ${ }^{38}$ Red-lining, conversely, implies that banks could increase their market share only by reducing interest rates and collateral requirements, but demur because they judge the probable returns insufficient.

While both credit rationing and red-lining force farmers to self-finance their projects, or shelve them entirely, they imply very different functions for both present and intending suppliers of rural financial services. Red-lining implies that, thanks to lower overheads, Raiffeisen banks were uniquely placed to offer financial services to first-time users by lowering prevailing prices. Credit rationing, by contrast, implies that cooperatives acted as niche players, serving borrowers excluded from credit markets because of the (perceived) riskiness of their line of business. When combined with credit rationing, the presence of information asymmetries may separate credit markets by risk-type: ${ }^{39}$ borrowers may self-select into different groups according to their risk profile, with high-risk borrowers seeking out lenders offering high interest rates and low collateral requirements, and low-risk borrowers seeking low interest rates and high collateral requirements. The question then is: were incumbents in rural financial markets in Ireland and the Netherlands engaging in red-lining, or credit rationing? If it was the latter: did rural financial markets segment? And: were cooperatives serving high-risk, low-risk or both types of customer?

The ignorance of the IAOS delegates to the 1898 parliamentary inquiry about the subject of JSBs - the major players in Ireland's rural economy - and their confusion over what constituted gombeenism indicate a serious lack of understanding in Ireland among cooperatives' instigators. ${ }^{40}$ The inquiry revealed that a JSB branch located where a new Raiffeisen society was set up had long ago closed for lack of business. Though the IAOS was told that Raiffeisen banks would have to open in places not served by JSBs, because these were already adequate for the areas in which they operated, it responded that cooperatives had advantages over JSBs and would benefit farmers wherever they were set up. At this stage, the IAOS felt that incumbents were credit rationing, and that their new cooperatives would be able to displace their competitors.

The later actions of the IAOS suggest that they gradually realised their own limitations, that they would struggle to outdo JSBs on their home turf. In 1902 the IAOS signed an agreement giving all cooperative enterprises concessional rates from the JSBs in return for promising not to let cooperative banks mobilize deposits. ${ }^{41}$ The IAOS then took trouble to declare that its Raiffeisen societies were not the JSBs' rivals. Indeed, in a government inquiry into agricultural credit in Ireland, George Russell, a charismatic IAOS official, described Raiffeisen societies as auxiliary JSBs, de facto

\footnotetext{
${ }^{38}$ Stiglitz and Weiss, 'Credit rationing'.

${ }^{39}$ Bester, 'Screening vs rationing'.

${ }^{40}$ Report from the S. C. (P.P. 1898). Regarding JSBs, their information was based on anecdotal accounts of banking practice.

${ }^{41}$ IAOS, Annual report 1904, p. 27; Third report of the R. C. (P.P. 1907), p. 55.
} 
branches in isolated areas. ${ }^{42}$ The IAOS appears to have turned around, deciding that Ireland's major financial services providers were not credit rationing, but rather red-lining, in refusing to serve the areas where they judged the returns were too low. In their view, it was up to Raiffeisen banks to serve there since they could reduce prevailing prices thanks to their unique ownership structure and business model. Their subsequent performance implies that these were insufficient.

Jonker and Brusse's micro-business histories of boerenleenbanken in the mostly Catholic southern Netherlands suggest that the market for agricultural credit was already satiated when cooperatives arrived. ${ }^{43}$ More generally, Rommes argues that Raiffeisen banks reached the Netherlands later than its neighbours precisely because other good sources were available. ${ }^{44}$ This argument implies that the sector's origins could not have been demand-led. Furthermore, Jonker shows that the new cooperative banks largely catered for savers, who could already use the Rijkspostspaarbank, a stateowned bank based on the POSB. He argues that the cooperatives created no new market for banking services, only unwanted extra competition. These studies suggest that the incumbents were credit rationing: credit was available, but the only way to attract more custom was to offer services to riskloving individuals willing to pay higher interest rates with low collateral requirements.

It is the contention here that boerenleenbanken succeeded because they changed the rules of the game: offering cheap integrated savings and loans services meant they could both displace competitors in, and further expand, the markets for savings and loans. Lower fixed costs came from not paying management, operating from cashiers' personal premises and opening only for short periods. ${ }^{45}$ Combined with a system of cosignatories and unlimited liability, these low costs meant low interest rates in return for higher, if non-traditional, collateral; Raiffeisen societies could poach lowrisk borrowers from incumbents, leaving only high-risk borrowers behind. The absence of bank failures among boerenleenbanken in the 1920s financial crisis is testament to this; cooperatives were cherry-picking the safe customers, ignoring the riskier ones implied in the arguments of Jonker, Brusse and Rommes.

What was the attitude of the cooperative movement's leaders towards incumbent credit suppliers? Irish cooperative propagandists reserved a special hatred for gombeenism, a term that had come to include all non-bank incumbents: moneylenders, loan sharks, and consumer credit. ${ }^{46}$ As

\footnotetext{
${ }^{42}$ Report of the D.C. (P.P. 1914), p. 63.

${ }^{43}$ Jonker, 'Welbegrepen eigenbelang'; Brusse, De dynamische regio.

${ }^{44}$ Rommes, Voor en door boeren?

${ }^{45}$ See, e.g., descriptions of various local boerenleenbanken in Vercauteren et al., Boeren gingen bankieren.

${ }^{46}$ See, e.g., the views of Plunkett, 'Agricultural organisation'; Finlay, 'The usurer in Ireland'; Report of the D.C. (P.P. 1914); Russell, Co-operation and nationality. The difficulty of defining "gombeenism" extends beyond contemporaries (Gibbon and Higgins, 'Patronage'; Kennedy, 'A sceptical view'; Gibbon and Higgins, 'The Irish "gombeenman"”).
} 
usurious moneylending was admittedly rare, the main butt of IAOS complaints was shopkeepers' credit: the difference between the prices of goods bought on credit and outright. Shopkeepers were also a target in the Netherlands: Van der Marck complains of them too. ${ }^{47}$ However, it is hard to ascertain the exact extent of gombeenism, if any, in either country. The baseline reports of the Congested District Board for Ireland (CDB), a development body for Ireland's poorest regions, suggest that effective interest rates were not extortionate. ${ }^{48}$ And in the Netherlands, rural producer cooperatives had shifted the balance of power from shopkeepers to farmers long before the advent of Raiffeisenism there. $^{49}$

Why then were cooperative banks successful only in the Netherlands, if the cooperatives' propaganda reveals a common foe? The crucial difference was that an Irish incumbent service provider had no Dutch equivalent: the deposit-mobilizing JSB.$^{50}$ In 1891, Ireland hosted nine such institutions, operating 533 branches, with 114 branches per million capita, holding $£ 34$ million in deposits; by 1911 the number of branches had increased to 813,189 branches per million capita, with deposits of $£ 57$ million. ${ }^{51}$ Although they did not serve the entire island, they operated an accessible network and were heavily used by agriculturalists. ${ }^{52}$ Even cooperatives used their clearing services. Branching in the Netherlands, however, commenced in earnest only after the Rotterdamsche Bankvereeniging started buying up provincial banking houses in the early 1910 s. $^{53}$ O'Gráda states that 'on balance, Irish farmers were creditors rather than debtors to [JSBs]'. ${ }^{54}$ In the Netherlands, Raiffeisen banks were predominantly used for savings, demonstrated by the finding that most banks were unleveraged. ${ }^{55}$ While Dutch farmers increasingly saved in the new cooperatives, Irish farmers did

\footnotetext{
${ }^{47}$ Van der Marck, Boerenleenbanken, pp. 7-8.

${ }^{48}$ Kennedy, 'Traders', argues that the late-nineteenth century explosion in the number of shopkeepers serving rural Ireland probably reduced the cost of credit. Even the IAOS recognised gombeenism was declining (Report from the S. C. (P.P. 1898)).

${ }^{49}$ Jonker, 'The alternative road', p. 121.

${ }^{50}$ The CDB found that 63 of the 84 districts identified as poor had access to JSBs; nearly everyone could obtain financial services (CDB baseline reports, Trinity College Dublin, OL Microfilms, 395).

${ }^{51}$ Thom's Directory, 1891 and 1911.

${ }^{52}$ Report from the S. C. (P.P. 1875). E.g., James H. Bealton, general manager at the Munster Bank, stated that 'the great bulk of the deposits are in small sums' and deposits came from small farmers (Q.2391, pp. 137-8).

${ }^{53}$ Colvin, 'Interlocking directorates'.

${ }^{54}$ Ó Gráda, Ireland, p. 262.

${ }^{55}$ Financial ratio analysis of banks' balance-sheets for the year 1919 suggests that most boerenleenbanken attracted more in savings than they lent out (calculated using CCB, Jaarverslag 1919; CCCB, Jaarverslag 1919; CCRB, Jaarverslag 1919).
} 
not, sticking instead to incumbents. Ironically, it was probably before the advent of Raiffeisen's cooperative ideas that the JSBs eradicated gombeenism in Ireland. ${ }^{56}$

As seen, Guinnane argues that the POSB was a major factor in explaining the Irish failure. However, his account of the POSB is somewhat mistaken; he states that 'deposits and withdrawals could be made in any amount ${ }^{57}$ From its inception, the POSB accepted deposits from one shilling to a maximum of $£ 30$ per year. ${ }^{58}$ It was not until 1915 that savings deposits escaped such limits, in order to obtain cheaper war finance. JSBs, not fully acknowledged as major incumbents in savings markets in rural Ireland by Guinnane, ${ }^{59}$ had no such limitations and accepted deposits as low as $£ 1 .{ }^{60}$ While the POSB did serve small savers - deposits under $£ 1$ were made by most of its depositors - these accounted for only about 9.5 per cent of its total deposits. ${ }^{61}$ The POSB required notice to withdraw involving formal application to its London headquarters, a process usually requiring a week. ${ }^{62}$ Raiffeisen cooperatives required a month's notice. ${ }^{63} \mathrm{JSB}$ s paid out on demand. More importantly still, the POSB did not provide the lending services of the JSBs, which granted loans, on similar terms to cooperative banks, from $£ 1$ upwards. ${ }^{64}$ Irish cooperatives did not, as Guinnane suggests, ${ }^{65}$ make longterm loans like their German counterparts; instead, loan terms were set at one year, with loans

\footnotetext{
${ }^{56}$ E.g. Northern Banking Company ex-chairman Kyle Knox argued that JSBs replaced the small lending of private lenders (D.C. minutes of evidence (P.P. 1914), Q.887a).

${ }^{57}$ Guinnane, 'A failed institutional transplant', p. 52.

${ }^{58}$ Eighth report of the Postmaster General, pp. 66-70.

${ }^{59}$ Guinnane, 'A failed institutional transplant', pp. 51-54.

${ }^{60} \mathrm{JSBs}$ were reported as accepting deposits as low as $£ 5$ in the 1860s by the organisers of Penny Savings Banks set up by Catholic charities (Society of St Vincent De Paul, Bulletin, p. 369). By 1914, Bank of Ireland director The O'Conor Don reports that his bank accepts $£ 1$ on deposit (D.C. minutes of evidence (P.P. 1914), Q.631). Anecdotal evidence suggests that farmers had savings in banks from which they borrowed (Report from the S. C. (P.P. 1884-85), Q.903; Plunkett 'Bankers and farmers in Ireland', p. 20), enabling JSBs to know better the conditions of borrowers.

${ }^{61}$ Figures refer to the UK POSB (Johnson, Saving and spending, p. 113).

${ }^{62}$ Ibid., p. 114.

${ }^{63}$ IAOS, Annual report 1899, appendix L, pp. 77-82, section XIII, rule a.

${ }^{64}$ Report from the S. C. (P.P. 1898), Q.2024, p. 105; Report from the S. C. (P.P. 1898), Q.2024, p. 105. The O'Conor Don stated that over 25 per cent of loans were for sum of $£ 10$ or under. The total amount of loans to farmers made by 12 Bank of Ireland branches between November 1911 and March 1912 was £260,389. Of this, the total loans under $£ 10$ were $£ 43,495$. Loan terms ranged from three to 12 months, with an understanding of renewal (D.C. minutes of evidence (P.P. 1914), Appendix 1, p. 513).

${ }^{65}$ Guinnane, 'A failed institutional transplant', p. 45.
} 
guaranteed by co-signers and repaid in regular instalments,${ }^{66}$ much like the JSB system of co-signed loans. The unrecognized debts mentioned by Guinnane were mortgage debts; Irish JSBs adapted to their market and were able to overcome any such problem by using personal guarantors in their loan contracts. Guarantors usually had to be known to their bank - through deposits - and would therefore have an incentive to monitor their peers. This incentive structure was absent in the Irish Raiffeisen banks, which did not mobilize deposits. In the sense of providing both savings and loans services, JSBs were functionally equivalent to both the Dutch and German Raiffeisen banks; the POSB was not.

Interest rates paid to customers of boerenleenbanken were sometimes one percentage point higher than those of the Rijkspostspaarbank $;{ }^{67}$ in Ireland the difference between interest rates offered by agricultural banks and those of the POSB was bigger still. ${ }^{68}$ But while boerenleenbanken easily poached the customers of the government's savings institution, or at least attracted more new customers, ${ }^{69}$ Ireland's Raiffeisen societies did not. Neither the Dutch nor the Irish institutional transplants had the state guarantee enjoyed by their post office rivals. Whereas Dutch Raiffeisen banks could independently attract deposits and did not have to use expensive outside financing, their Irish cousins relied on concessional state loans and interbank borrowing to fund their loan books and channelled any excess savings through JSBs. ${ }^{70}$ In the tense political environment of the Land Wars, Irish savers appear to have preferred the safety of the POSB guarantee, remembering in particular the frauds and failures of municipal savings banks. ${ }^{71}$ Dutch depositors had no such fears and chose whichever institution offered the highest return, or at least whichever represented their social views more closely (section V). It was the activities in the market for deposits that enabled boerenleenbanken to operate so successfully in the market for loans. Tellingly, the few Irish Raiffeisen

\footnotetext{
${ }^{66}$ The annual total figure for Raiffeisen loans was $£ 55,855$ in 1910 , and 'a not insignificant portion of this amount is probably represented by renewals of loans' (Report of the D.C. (P.P. 1914), p. 206). For loan terms, see IAOS, Annual report 1899, appendix L, pp. 77-82, section XII, rules e \& g, and Report of the D. C. (P.P. 1914), appendix 22, section xi, rule e.

${ }^{67}$ Weststrate, Gedenkboek.

${ }^{68}$ Report of the D. C. (P.P. 1914), p. 164.

${ }^{69}$ Van Zanden, 'Old rules', p. 127, estimates that the Rijkspostspaarbank held 7.8 per cent of all bank assets in 1900 but 5 per cent in 1918, while boerenleenbanken went from 0.1 to 4.2 per cent in the same period.

${ }^{70}$ Guinnane, 'Trust', argues that Irish cooperators 'trusted each other not to be too adamant about repaying loans' because these loans were funded by the government, which could not credibly punish non-repayment, whereas fellow cooperators could.

${ }^{71}$ McLaughlin, 'Prolifigacy'.
} 
societies that could mobilize savings proved to be the most durable, such as the Columbkille Raiffeisen bank in Co. Longford. ${ }^{72}$

\section{IV}

The horizontal and vertical integration of cooperative enterprises was a key feature of Raiffeisenism in Germany and its imitation in the Netherlands; does its absence in Ireland help explain its divergent history? The lack of vertical integration in Ireland did not go unnoticed by contemporaries. Hugh de Fellenberg Montgomery, a leading Unionist landlord who investigated banks in Germany in 1903 on behalf of the Irish government's Department of Agriculture and Technical Instruction (DATI), wrote: ${ }^{73}$

In many respects the Raiffeisen Organisation offers, probably, the best model for the organisation of agricultural co-operative societies; but the difficulty of adopting it as a pattern for Irish agricultural co-operative organisation arises from the circumstance that it is specially framed for the benefit of savings and loan societies doing supply business and that productive societies (dairy societies \&c.) were an afterthought in this organisation. [...] In Ireland the dairy societies came first, the supply associations next, and the credit societies last. [italics sic]

A British parliamentary inquiry also discussed the value of vertical integration for Ireland, highlighting as institutional best practice the German custom of integrating cooperative banks and wholesale purchasers. ${ }^{74}$ Indeed, Deeg suggests that German cooperative banks could be viewed as functionally equivalent to universal banks, ${ }^{75}$ Germany's integrated commercial and investment banking conglomerates, which overlapped management with the enterprises they financed and had similarly wide spectra of financial services.

From a theoretical perspective, vertical and horizontal integration can be seen as an important advantage of cooperative enterprise: providing economies of scale and scope, eliminating double marginalisation, and, perhaps more importantly, combating ex post moral hazard with cheap information on income flows from farming enterprises. The importance of associating with other cooperatives may also reflect cross-subsidization within the cooperative structure; other parts of the vertically-integrated business may have been more profitable, or may have had access to better management. Horizontal integration was common in Germany and the Netherlands through central banks which enabled the Raiffeisen societies to diversify risk and re-distribute surplus local savings. This important aspect of Raiffeisenism was not encouraged in Ireland, but some of these advantages were captured instead by JSBs through branching and mobilizing savings deposits.

\footnotetext{
${ }^{72}$ This society was also related to the local cooperative creamery (National Archive of Ireland (henceforth NAI), ICOS archive, Columbkille Credit Society, 1088/253a/2).

${ }^{73}$ Montgomery, 'Agricultural co-operation', p. 247.

${ }^{74}$ Reports from Her Majesty's representatives (P.P. 1895), p. 22. Similar arguments are advanced in Darling, Some aspects, p. 36, and Finlay, 'Co-operative Agricultural Societies in Germany'.

${ }^{75}$ Deeg, 'On the development', p. 101.
} 
Douma uses transaction cost economics to explain why cooperative businesses proved more successful in some markets than others. ${ }^{76} \mathrm{He}$ posits that different forms of business organization compete with one another, and that following a shakeout, only those that prove to be most suited to their business environment survive. Using the case of the Dutch dairy industry in the late nineteenth century, he argues that cooperative dairies could not displace private creameries in urban areas because the latter had invested in sophisticated fresh milk distribution networks. The cooperative form proved better suited to rural banking; their organizational form let boerenleenbanken displace kassiers for loan customers and the Rijkspostspaarbank for depositors. Cooperatives were most appropriate where the costs of downstream business were too high for conventionally owned banks to profit. Dutch cooperatives enjoyed a high degree of enforced vertical integration; Raiffeisen banks there often stipulated that members also belong to the local chapter of a (confessional) farming union. Other cooperative enterprises, such as cooperative dairies, became institutional members, sharing management expertise. ${ }^{77}$

Meanwhile, in Ireland, alternative types of cooperative enterprise with similar functions were promoted independently, effectively competing with one another; cooperative dairies and purchasing stores also offered short-term credit to members and 'creamery loans' were reported as being in significantly higher supply than loans from cooperative banks. ${ }^{78}$ There were a few notable exceptions where Raiffeisen societies were vertically integrated into other local cooperatives; some surviving correspondence from agricultural banks was written on the stationery of dairy cooperatives, suggesting at the very least overlapping management. ${ }^{79}$ On the whole, however, Irish Raiffeisen banks did not enjoy the same success; unable or unwilling to integrate, they were judged by Ireland's agricultural cooperatives to be inefficient and costly alternatives to JSBs.

As Guinnane highlights, Ireland's cooperative banks never integrated horizontally, developing neither audit unions nor cooperative clearinghouses. ${ }^{80}$ The IAOS performed auditing duties, but expensively and it soon chose instead to focus on more profitable aspects of its cooperative portfolio:

\footnotetext{
${ }^{76}$ Douma, 'Waarom bestaan coöperaties?'; Douma and Schreuder, Economic approaches, pp. 172-3.

${ }^{77}$ Integration was helped by dense networks of mutual loan cosignatories, which encouraged information sharing (Sowers, 'The role of social networks').

${ }^{78}$ See, e.g., Report of the Chief Registrar (1909), pp. 200-229.

${ }^{79}$ See, e.g., the case of the Ballymoyer credit cooperative, Co. Armagh, whose letterhead ran, 'The Whitecross agricultural and dairy co-operative' (NAI, ICOS archive, Letter from J. McDermott [manager Ballymoyer Credit society] to IAOS secretary, 15 June 1910, 1088/79/1).

${ }^{80}$ Guinnane, 'A failed institutional transplant'. This absence of a federation did not hamper Ireland's comparatively successful cooperative creameries (Breathnach, 'The diffusion', p. 4), which could overcome $e x$ post moral hazard problems by demanding future milk production as loan security (see, e.g., Report of the D.C.
} (P.P. 1914), Q.5802-5803). 
creameries and stores. The IAOS had threatened to establish its own central clearinghouse in 1901; it did so in order to force JSBs to lend to the wider cooperative movement at concessional rates of interest. ${ }^{81}$ As noted, a favourable agreement was reached in return for the promise of cooperative banks not to mobilize savings but instead use JSBs as de facto clearing houses. While this may have hurt them in the long run, at the time this was an expedient solution - a case of cooperative realpolitik. Concessional loans from various government bodies were their other source of funding. Irish Raiffeisen banks' structure of liabilities could be maintained only if these arrangements were static, an unlikely prospect: after political wrangling government bodies withdrew their support for Raiffeisen banks, while volatile international markets following the 1907 financial crisis saw JSBs unilaterally alter the IAOS-brokered agreements. ${ }^{82}$ In summary, the IAOS chose to forgo horizontal integration for its cooperatives, and in the process weakened the balance-sheets of its Raiffeisen banks and undermined the case for vertical integration, since other parts of the IAOS portfolio were able to access non-cooperative financial services. ${ }^{83}$

This lack of horizontal and vertical cooperative integration in Ireland may have resulted from the way that cooperative enterprises were established there, in contrast with the Netherlands' case. Most discussion in the cooperative literature on the development of central institutions emphasises individual cooperatives combining at a "higher level" ${ }^{84}$ While this characterisation roughly applies to the Netherlands, in Ireland the sequence was more definitely reversed; there the central organization created local cooperatives, in top-down development. The IAOS established the first Irish Raiffeisen society in Doneraile, Co. Cork, in 1894. It was not until 1912, the twilight of Irish Raiffeisenism, that the first cooperative enterprise was founded on the initiative of farmers, because 'in former years the initiative had been taken in all cases by our [IAOS] organisers'. ${ }^{85}$

The role of the IAOS was outlined by IAOS President, Horace Plunkett, as follows: 'In the first instance it was to consist of philanthropic persons, but its constitution provided for the inclusion in its membership of the societies which had already been created and those which it would itself create as time went on' ${ }^{86}$ Giving evidence in a money-lending inquiry, he said that the role of the

\footnotetext{
${ }^{81}$ IAOS, Annual report 1901, pp. 10-13. Raiffeisen banks incorporated as unlimited liability societies were legally barred from establishing their own federated clearinghouse, a side-effect of the restrictions imposed on Friendly Societies.

${ }^{82}$ IAOS, Annual report 1908, p. 12.

${ }^{83}$ Lack of vertical integration did not hamper the development of Irish dairies. In this respect these enterprises mirror the Danish ones on which they were modelled (O'Rourke, 'Culture, conflict and cooperation'), where the economic function of JSBs was fulfilled by songesparekasser.

${ }^{84}$ Birchall, The international co-operative movement.

${ }^{85}$ IAOS, Annual report 1912, p. 3.

${ }^{86}$ Plunkett, Ireland in the new century, p. 192.
} 
IAOS was to 'persuade' people to adopt cooperation, which it did by hiring travelling organizers to talk to rural groups and explain the benefits of cooperative methods. George Russell, one such organizer, enticed the crowds with promises of concessional state loans. ${ }^{87}$ Meanwhile, in the Netherlands, propagandists were significantly more active in Catholic networks; priests were invited to lecture at special meetings of the Catholic farmers' unions on the benefits of cooperative banking. ${ }^{88}$ The central bank would then provide farmers with the necessary literature and legal advice to set up a local bank. ${ }^{89}$ Unlike the Irish case, however, the propaganda often continued long after a cooperative's original foundation; the Catholic Church maintained informal links with "their" cooperatives by installing parish priests or other church officials as spiritual advisers to their board of directors. ${ }^{90}$ It is this link between banking and religion, the subject of the following section, which appears to have been key to the Dutch success.

\section{$\mathbf{V}$}

Ostensibly, Ireland had a similar confessional divide to the Netherlands. But while Dutch cooperatives benefited from religious and economic division, their Irish counterparts did not. While division led to peaceful segregation in Dutch rural society, it was a major cause of social strife on the island of Ireland. This is especially apparent from contrasting the histories of the Dutch and Irish cooperative movements' apex institutions.

By the late nineteenth century, most Dutch citizens identified themselves with a particular religious denomination, primarily Roman Catholicism, and the liberal hervormde (Dutch Reformed) and orthodox gereformeerde (literally "re-reformed") forms of Calvinism. Dutch enterprise and society intensified segregation along religious lines, with different Christian denominations developing sophisticated parallel economies in a process of verzuiling, each with its own schools, political parties, newspapers, trade unions, hospitals and even banks. The argument put forward, or implied, in the existing literature is that socio-political interest groups - the Catholic clergy above all -

\footnotetext{
${ }^{87}$ Gallagher, My story, p. 63.

${ }^{88}$ Borst, 'De Coöperatieve Centrale', recounts how one such organizer operated in the province of NoordHolland.

${ }^{89}$ This narrative is consistent with the establishment, in 1919, of the first boerenleenbank in Loosduinen (Archief Rabobank Haaglanden (henceforth ARH), The Hague, Notulen Algemene Vergaderingen Loosduinen I).

${ }^{90}$ The Catholic boerenleenbank in Rijswijk, a village neighbouring Loosduinen, was run by a Sunday-school teacher and met in the school building (Rijswijk Historisch Informatiecentrum (henceforth RHI), Rijswijk ZH, 80 jaar Rabobank Rijswijk, J. Janse, 1990). Protestant-led banks were also established with the help of local elites, illustrated by the involvement of the village doctor in Capelle (Vercauteren et al., Boeren gingen bankieren).
} 
were crucial in creating the first cooperative banks; these groups viewed cooperatives as a way of consolidating or extending their political influence. ${ }^{91}$

The verzuiling of Dutch cooperation was a function of the earlier confessionalization of rural agricultural politics. A national Nederlandsch Landbouw-Comité (NLC) was established in 1884 to stimulate the improvement of agricultural technology and tackle disease in cattle. ${ }^{92}$ However, the Catholic press argued that this new grouping did not benefit Catholics as much as Protestants. Support grew for the creation of Catholic-only enterprises in response to Rerum Novarum, a Papal Encyclical in support of anti-socialist confessional trade unionism. ${ }^{93}$ A new organization for Dutch agriculturalists emerged in 1895: the Nederlandsche Boerenbond (NBB). The creation of federated regional unions followed, the largest of which was the Noordbrabantse Christelijke Boerenbond (NCB). These organizations poached the NLC's members, or at least mobilized segments of rural society traditionally overlooked by the NLC. The new unions were predominantly Catholic: in 1904, farmers in the Catholic provinces (Noord-Brabant and Limburg) made up 73 per cent of the NBB's membership, and these groupings were dominated by Catholics even in predominantly Protestant northern provinces. ${ }^{94}$

Largely for geopolitical reasons, serious conflict soon arose between regional and federal unions, the NBB and the NCB. In 1898 this led to establishing two central banks for the Netherlands' new boerenleenbanken, one based in Utrecht and sponsored by the NBB, the other, based in Eindhoven, by the NCB. The NBB's bank rapidly changed to a neutral institution and formally disaffiliated from the NBB, but the NCB's central bank kept its requirement that members sign up to religious principles: 'furthering the interest of God, the family and property'. ${ }^{95}$ In consequence, new boerenleenbanken established after 1898 could choose their network: Catholics generally chose Eindhoven because it more closely represented their interests, while Protestants chose Utrecht, because it was different. ${ }^{96}$ The confessionalization of apex institutions resulted in a de facto confessionalization of local Raiffeisen units, with a bank for each Christian denomination in many villages. The foundation date of many banks suggests a reaction to the establishment nearby of one for

\footnotetext{
${ }^{91}$ Jonker, 'Welbegrepen eigenbelang'; Sluyterman et al., Het coöperatieve alternatief; Van Zanden and Van Riel, The strictures of inheritance; Rommes, Voor en door boeren?

${ }^{92}$ Smits, Boeren met beleid.

${ }^{93}$ Pecci, Rerum novarum. No evidence has been found that this encyclical influenced the Irish clergy.

${ }^{94}$ Smits, Boeren met beleid.

${ }^{95}$ E.g., the statutes of the boerenleenbank in Baardwijk, Noord-Brabant, include a typical clause to this effect (ARL, Statuten Boerenleenbank te Baardwijk).

${ }^{96}$ One additional, regional, central bank was established in 1904, for Catholics residing in the provinces of Holland. This proved unsuccessful, however; it was closed in 1924 following serious mismanagement (Borst, 'De Coöperatieve Centrale').
} 
another denomination. ${ }^{97}$ Banks benefited from catering exclusively for one religious community; peer monitoring was easier, and social sanctions while cheaper to administer were more costly for offenders.

Meanwhile, in Ireland, rather than embrace and use confessional politics to their advantage, cooperative leaders tried initially to avoid this; they never actively took advantage of the polity's religious and political split as the Dutch had. ${ }^{98}$ O'Rourke argues that the political divisions following from sectarianism were actively antipathetic towards dairy cooperation. ${ }^{99}$ It is unclear whether the same held true for Raiffeisen societies, since most were located among a relatively homogenous population, in terms of religious and political affiliation. And, unlike the Netherlands, they had only one apex institution, the IAOS, which had declared itself to be non-religious and apolitical; Protestants and Roman Catholics were involved at the highest levels of its management. While rare, a few incidents can be found which together suggest that socioreligious divisions may have contributed towards the failure of Irish Raiffeisenism. One example comes from the village of Cliff in Co. Sligo, where 91 per cent of the population was Catholic. In a letter to IAOS secretary R. A. Anderson, local IAOS organizer Paul Gregan writes that he fears 'the fires of political and religious dissension' may lead to the bank's downfall, for the local Catholic population had 'retreated' from the bank. ${ }^{100}$

Political divisions were, however, extremely important at the national level, given that most Raiffeisen societies depended on concessional loans from government bodies. Besides being IAOS president, Horace Plunkett was a sitting MP (1892-1900), a member of the CDB and vice-president of DATI; his position gave him influence on governmental policy towards Raiffeisen banks. When Plunkett lost his parliamentary seat in 1900, he anomalously held the junior ministerial post of vicepresident of DATI for five more years. He was removed from office only after changes in government. Plunkett's successor at DATI was T. W. Russell, who, it is claimed, was openly hostile towards all forms of cooperation. ${ }^{101}$ Anderson highlights his antipathy to credit cooperatives: 'He [Russell] declared publicly that the system under which the credit societies were formed was "rotten and indefensible" and gave it as his opinion that the $£ 24,000$ lent by the Board was "not worth more than

\footnotetext{
${ }^{97}$ A second boerenleenbank, this time for non-Catholics, was established in Rijswijk only months after the first, in 1910 (RHI, 80 jaar Rabobank Rijswijk). A second bank was established in Loosduinen in 1916 by disaffected Catholics (ARH, Bestuursnotulen Loosduinen I) following the example of a new Catholic-only horticultural auction house (Vijverberg, 'Het Loosduinse'). Business histories of boerenlenbanken elsewhere document a similar pattern (Moolenbel, Tussen plak en euro; Rabobank Gemeente Voorst, Een eeuw).

${ }^{98}$ Ollerenshaw, The Belfast banks, pp. 157-163, finds that JSBs were not apolitical; northern banks provided covert support for Unionist causes and the Hibernian Bank was supported by nationalists.

${ }^{99}$ O’Rourke, 'Culture, conflict and cooperation'.

${ }^{100}$ NAI, ICOS Archive, Cliff Agricultural Bank, 8 July 1900, 1088/206A/1.

${ }^{101}$ West, Horace Plunkett, pp. 75 \& 83.
} 
half a crown in the $£ . "{ }^{102}$ Following Russell's appointment, various government bodies began reviewing the policy of concessional loans, which explains in part the timing of the divergence in cooperative banks per capita in figure 1 .

Confessionalization in the Netherlands had other advantages; clerical and teacher involvement in the running of their Raiffeisen societies were important aspects of cooperation. As mentioned, many banks had priests as spiritual advisors to their boards. Although their influence varied considerably, in some banks these priests had de facto power of veto over bank decision making, strengthening the link between congregation and clientele. ${ }^{103}$ However, in Ireland, clerical assistance was not widespread, despite the prominent support of the Jesuit priest Thomas Finlay, professor of political economy at University College Dublin. ${ }^{104}$ Catholic priests were, if anything, apathetic towards mutual societies; the assistant commissioner for Friendly Societies in Ireland in the 1870s noted: 'Roman Catholic clergymen have $[\ldots]$ never used their very great influence to promote these institutions; but I must in justice say that I have met with no instance of a Roman Catholic clergymen thwarting them in any way, or denouncing them'. ${ }^{105}$

The Irish Catholic clergy was not a homogeneous body and clerical support was probably determined by numerous conflicting factors. Kennedy notes: 'without doubt the clergy entertained a general sympathy for any attempts that might appear to promote the economic prosperity of their congregations, provided there were no adverse side-effects as viewed from the vantage point of the Catholic Church'. ${ }^{106}$ If cooperative ventures threatened the economic interests of the Church, or those of its prominent financial contributors, or if direct kinship ties were at risk, the clergy could even actively oppose cooperation. Given that the IAOS had declared that Raiffeisen societies were to be used to attack gombeenism, or rather rural shopkeepers, they might if successful have impinged on the wealthier patrons of the Church; the mixed loyalties of the clergy help to explain its lack of participation in Raiffeisen societies. ${ }^{107}$ Clerical involvement would certainly have been useful; priests could have been an important link between businesses and the society they served. There was already a de facto confessionalization of the Irish education system, leading to clerical control over the patronage of schools ${ }^{108}$ clerical involvement in cooperatives could have encouraged local teachers to act as cooperatives' treasurers, in much the same way as they did in the Netherlands.

\footnotetext{
${ }^{102}$ Anderson, With Plunkett, p. 256.

${ }^{103}$ Vercauteren et al., Boeren gingen bankieren.

${ }^{104}$ Finlay, 'Agricultural Co-operation in Ireland'.

${ }^{105}$ Friendly and Benefit Building Societies’ Commission (P.P. 1875), p. 3.

${ }^{106}$ Kennedy, 'The early response', p. 69.

${ }^{107}$ This lack of support may have led to the publication of Plunkett, Ireland, which exhorted the view, reminiscent of Weber, The Protestant ethic, that Roman Catholicism had harmed Irish economic development.

${ }^{108}$ Akenson, The Irish education experiment.
} 
Limited versus unlimited liability was a divisive issue across Europe; many influential actors in both Ireland and the Netherlands believed unlimited liability constrained cooperative banking. ${ }^{109}$ From an asset pricing perspective, unlimited liability means that debt holders have full recourse, thus shareholders give more weight to both tails of asset returns, encouraging them to monitor more closely the efforts of their peers. Unlimited liability implies that if a credit cooperative were to fold, all its members would be liable for all outstanding debts. But it does not imply that the liability would be shared equally; if the asset holdings of members were not homogeneous, then those with more assets (i.e. more deposits) would be forced to contribute more to any settlement. As all cooperatives chose unlimited liability in accordance with Raiffeisen's principles, there could in theory have been some reluctance to join them. In practice, this was a problem only in Ireland. Why?

When JSBs were formed in the early nineteenth century, they were established as unlimited liability enterprises. By the advent of Raiffeisen institutions, most of the polity's banks had limited their liability in some way. ${ }^{110}$ Before limited liability was introduced to the UK, contemporary observers of the banking system often complained that unlimited liability attracted low-wealth individuals and repelled the wealthy. ${ }^{111}$ It was argued that choosing unlimited liability resulted in a de facto limitation in any case: too little information on the financial assets of shareholding peers discourages wealthier shareholders from participating. However, using data on the composition of bank shareholders in the last quarter of the nineteenth century, before and after the limitation of Ulster Bank shareholders' liability, Acheson and Turner show that this limitation increased if anything the proportion of equity-holders with low wealth. ${ }^{112}$ What makes Raiffeisen banks so different from JSBs is that shareholdings were not valuable: purchasing a share in a JSB required substantial sums of money to be surrendered, whatever eventual additional liability claim came with it, while joining a Raiffeisen bank required merely a signature. "Shareholders" in Raiffeisen societies may therefore have been of the poor quality identified by contemporaries.

Rural Ireland was not a homogeneous society; to ensure success, a credit cooperative required participation from diverse interests. Other cooperative enterprises (dairies, stores) were limited liability organizations, registered under the more favourable acts covering industrial and provident

\footnotetext{
${ }^{109}$ E.g., De Nederlandsche Bank, the Dutch de facto central bank, refused many cooperatives access to its discount window because their choice of legal liability meant they had little disposable capital (De Vries, 'Geschiedenis'; Sluyterman et al., Het coöperatieve alternatief).

${ }^{110}$ Acheson and Turner, 'The impact of limited liability'.

111 Turner, "The last acre and sixpence"”.

${ }^{112}$ Acheson and Turner, 'The impact of limited liability'.
} 
societies. Lee argues that the unlimited liability clause hampered the outreach capacity theoretically enjoyed by such business organizations, because members may have voted to exclude those with insufficient means. ${ }^{113}$ Land occupation statistics support an unequal distribution: in 1894, when Raiffeisen societies first came to Ireland, 84 per cent of farms were smaller than 12 hectares, and 16 per cent, the wealthiest, exceeded 20 hectares. ${ }^{114}$ Conversely to Lee's argument, it is highly plausible that large land occupiers were discouraged from participating in Raiffeisen societies. Moreover, wealthier landholders had no pressing need to join one, having access to other credit streams, including limited liability cooperative creameries, and could invest in various financial securities, including JSB shares, in their local communities. ${ }^{115}$ The result was that the most "desirable" members were absent from the Raiffeisen projects of many villages, rendering them unsustainable in the long run. If the wealthier members of Irish society had joined Raiffeisen banks, contributing their knowledge, expertise and wealth, the quality of leadership and administration might have been enhanced.

Unlike Ireland, the Netherlands had no equivalent to the rural JSBs. Provincial banking houses were small partnerships, and large joint stock commercial banks of Amsterdam and Rotterdam began branching only in the early 1910s. While wealthy Irish agriculturalists could access a local JSB branch, their Dutch counterparts had no such option. Like Ireland, Dutch society was not homogenous in terms of wealth-holding, but verzuiling ensured that communities were instead homogenous in terms of socioreligious identity. Raiffeisenism became an attractive proposition for the rural elite, also; betteroff Dutch farmers overcame the problems associated with the lack of valuable shareholding suffered by Ireland's Raiffeisen banks with peer monitoring and social punishment. They even helped to run their banks, taking full advantage of their socioreligious proximity to their less-wealthy peers.

\section{VII}

By comparing Ireland and the Netherlands, this article argues that the latter promoted Raiffeisenism successfully because: (1) Dutch Raiffeisen banks mobilized members' savings, while their Irish counterparts did not; (2) unlike Irish ones, Dutch cooperative enterprises were highly integrated into the rural economy; and (3) Raiffeisen societies took advantage of the segregation of Dutch society, while Irish socioreligious and socioeconomic divisions militated against their successful development. While reason (1) was probably the most important, it was insufficient alone to ensure their success. Conversely, it is doubtful whether Irish cooperatives would have succeeded if they had been more

\footnotetext{
${ }^{113}$ Lee, The modernisation of Irish society.

${ }^{114}$ Agricultural statistics of Ireland (P.P. 1894).

${ }^{115}$ Acheson and Turner, 'The impact of limited liability', estimate that farmers constituted 18 per cent of Ulster Bank's shareholders (p. 334).
} 
integrated, horizontally or vertically, or able to take advantage of Irish social divisions, without also being able to mobilize rural savings on a large scale.

Together, this paper's three categories of reasons for the divergent performance of Raiffeisenism abroad inform a new comparison of the financial functions performed by cooperative banks for rural customers. Of five functions that Merton argues to be key to any financial service sector, the Dutch boerenleenbanken performed four and Irish agricultural banks two only (see table 4). In particular, Ireland's Raiffeisen societies failed to provide ways of managing uncertainty and risk and to minimize information asymmetries and incentive problems. Incumbent institutions already performed these functions and probably benefited from being first-movers; no institutional advantages were gained from the peculiar design of Raiffeisen's banks in the Irish context.

\section{[Insert table 4]}

As discussed in the introduction, this article is motivated by the pioneering work of Guinnane, who argues that Irish cooperatives were a failure for three reasons: (1) competition in savings markets from the POSB; (2) the weakness of the IAOS as an apex institution; and (3) detrimental norms peculiar to Irish society. ${ }^{116}$ This article strengthens and revises Guinnane's conclusions as follows: (1) it was competition from JSBs rather than the POSB that hampered Raiffeisenism in Ireland, competitors largely absent from Dutch markets, where a post office bank also operated; (2) the IAOS chose not to establish a federated clearinghouse to survive this competition, while Dutch apex institutions were free to fully integrate into the rural economy; and (3) the poor trust Guinnane observes in Irish society can be explained by socioreligious and socioeconomic division.

In conclusion, in light of the discussion in this article, Guinnane may be said to have asked the wrong question; the issue is not why Raiffeisen banks failed in Ireland, but rather why they succeeded in the Netherlands. The Netherlands had a highly segmented market, with different specialist financial institutions serving different groups. Raiffeisen banks could take advantage of a large, still mostly unpopulated niche within this market, unpopulated, at least, by banks that could reap full benefit from embedding themselves in their society. In contrast, Ireland enjoyed competitive, unsegmented markets in which incumbents, such as JSBs and savings banks, already offered rural societies a full complement of financial services; new entrants had little room and little advantage was to be gained from cooperative ownership.

\footnotetext{
${ }^{116}$ Guinnane, 'A failed institutional transplant'.
} 


\section{Footnote references}

Acheson, G. G. and Turner, J. D., 'The impact of limited liability on ownership and control: Irish banking, 1877-1914', Economic History Review, LIX (2006), pp. 320-346.

Akenson, D. H., The Irish education experiment: the national system of education in the nineteenth century (1970).

Albrecht, C., 'Nationalism in the cooperative movement in Bohemia before 1914', in T. Lorenz, ed., Cooperatives in ethnic conflicts: Eastern Europe in the 19th and early 20th century (Berlin, 2006), pp. 215-227.

Anderson, R. A., With Plunkett in Ireland: the co-op organiser's story (1935).

Baltensperger, E., 'Credit rationing: issues and questions', Journal of Money, Credit and Banking, 10 (1978), pp. 170-183.

Banerjee, A. V., Besley, T. and Guinnane, T. W., 'Thy neighbor's keeper: the design of a credit cooperative with theory and test', Quarterly Journal of Economics, 109 (1994), pp. 491-515.

Bátiz-Lazo, B. and Billings, M., 'New perspectives on not-for-profit financial institutions: organisational form, performance and governance', Business History, 54 (2012), pp. 309-324.

Bester, H., 'Screening vs rationing in credit markets with imperfect information', The American Economic Review, 75 (1985), pp. 850-855.

Bieleman, J., Boeren in Nederland: geschiedenis van de landbouw 1500-2000 (Amsterdam, 2008).

Birchall, J., The international co-operative movement (Manchester, 1997).

Borst, C. J. A., 'De Coöperatieve Centrale Christelijke Boerenleenbank gevestigd te Alkmaar 1904-1924' (unpub. MA dissertation, Hogeschool InHolland, Haarlem, 2004).

Breathnach, P., 'The diffusion of the co-operative creamery system in Ireland, 1889-1920: A spatial analysis' (unpub. PhD thesis, National University of Ireland, Maynooth, 2006).

Brusse, P., De dynamische regio. Economie, overheid en ondernemerschap in West-Brabant vanaf 1850 (Utrecht, 2008).

Campen, P. C. M., Hollenberg, P. and Kriellaars, F., Landbouw en landbouwcrediet 1898-1948: vijftig jaar geschiedenis van de Coöperatieve Centrale Boerenleenbank Eindhoven (Roermond, 1948).

Capie, F. and Wood, G., 'Great Depression of 1873-1896', in D. Glasner, ed., Business cycles and depressions: an encyclopedia (New York, 1997), pp. 148-149.

Colvin, C. L., 'Religion, competition and liability: Dutch cooperative banking in crisis, 1919-1927' (unpub. PhD thesis, London School of Economics and Political Science, 2011)

Colvin, C. L., 'Interlocking directorates and conflicts of interest: the Rotterdamsche Bankvereeniging, Müller \& Co. and the Dutch financial crisis of the 1920s', Business History (2013).

Coöperatieve Centrale Boerenleenbank (CCB), Jaarverslagen, 1904-1919 (Eindhoven).

Coöperatieve Centrale Christelijke Boerenleenbank (CCCB), Jaarverslagen, 1904-1919 (Alkmaar).

Coöperatieve Centrale Raiffeisen-Bank (CCRB), Jaarverslagen, 1904-1919 (Utrecht).

Darling, M. L., Some aspects of co-operation in Germany, Italy and Ireland (Lahore, 1922).

Deeg, R., 'On the development of universal banking in Germany', in D. J. Forsyth and D. Verdier, eds., The origins of national financial systems: Alexander Gerschenkron reconsidered (New York, 2003), pp. 64-86.

Digby, M., The world co-operative movement (2nd edn., 1960).

Douma, S., 'Waarom bestaan coöperaties?', Maandblad voor Accountancy en Bedrijfseconomie, June (2001), pp. $248-255$.

Douma, S. and Schreuder, H., Economic approaches to organizations (Harlow, 4th edn., 2008).

Eijnatten, J. van and Lieburg, F. van, Nederlandse religiegeschiedenis (Hilversum, 2nd edn., 2006).

Finlay, T. A., 'Co-operative Agricultural Societies in Germany', Statistical and Social Inquiry Society of Ireland, 72 (1891), pp. 605-613.

Finlay, T. A., 'The usurer in Ireland', The New Ireland Review, 1 (1894), pp. 304-316.

Finlay, T. A., 'Agricultural co-operation in Ireland', The Economic Journal, 6 (1896), pp. 204-211.

Freixas, X. and Rochet, J.-C., Microeconomics of banking (Cambridge MA, 2nd edn., 2008). 
Galassi, F. L., 'Measuring social capital: culture as an explanation of Italy's economic dualism', European Review of Economic History, 5 (2001), pp. 29-59.

Gallagher, P., My story by Paddy the Cope (1939).

Garrido, S., 'Why did most cooperatives fail? Spanish agricultural cooperation in the early twentieth century', Rural History, 18 (2007), pp. 183-200.

Ghatak, M. and Guinnane, T. W., 'The economics of lending with joint liability: theory and practice', Journal of Development Economics, 60 (1999), pp. 195-228.

Gibbon, P. and Higgins, M. D., 'Patronage, tradition and modernisation: the case of the Irish "gombeenman"', The Economic and Social Review, 6 (1974), pp. 27-44.

Gibbon, P. and Higgins, M. D., 'The Irish “gombeenman”: re-incarnation or rehabilitation', The Economic and Social Review, 8 (1977), pp. 313-320.

Guinnane, T. W., 'A failed institutional transplant: Raiffeisen's credit cooperatives in Ireland, 1894-1914', Explorations in Economic History, 31 (1994), pp. 38-61.

Guinnane, T. W., 'Cooperatives as information machines: German rural credit cooperatives, 1883-1914', The Journal of Economic History, 61 (2001), pp. 366-389.

Guinnane, T. W., 'Delegated monitors, large and small: Germany's banking system, 1800-1914', Journal of Economic Literature, 40 (2002), pp. 73-124.

Guinnane, T. W., 'A “friend and advisor”: external auditing and confidence in Germany's credit cooperatives, 1889-1914', Business History Review, 77 (2003), pp. 235-264.

Guinnane, T. W., 'Trust: a concept too many’, Jahrbuch für Wirtschaftsgeschichte, (2005), pp. 77-92.

Guinnane, T. W., 'The early German credit cooperatives and microfinance organizations today: similarities and differences', in B. Armendáriz and M. Labie, eds., The handbook of microfinance (Singapore, 2011), pp. 77-100.

Guinnane, T. W. and Henriksen, I., 'Why Danish credit co-operatives were so unimportant', Scandinavian Economic History Review, 46 (1998), pp. 32-54.

Henning, F.-W., 'Deutsche wirtschafts- und sozialgeschichte im 19. Jahrhundert', vol. 2 of Handbuch der wirtschafts- und sozialgeschichte Deutschlands (Paderborn, 1996).

Henriksen, I., Lampe, M. and Sharp, P., 'The strange birth of liberal Denmark: Danish trade protection and growth of the dairy industry since the mid-nineteenth century', Economic History Review, 65 (2011), pp. 770-788.

Hobsbawm, E., The age of empire 1875-1914 (1987).

Hollis, A. and Sweetman, A., 'Microcredit: what can we learn from the past?', World Development, 26 (1998), pp. 18751891.

Irish Agricultural Organisation Society (IAOS), Annual reports, 1899-1920 (Dublin).

Johnson, P., Saving and spending: the working class economy in Britain 1870-1939 (Oxford, 1985).

Jonker, J., 'Welbegrepen eigenbelang; ontstaan en werkwijze van boerenleenbanken in Noord-Brabant, 1900-1920', Jaarboek voor de Geschiedenis van Bedrijf en Techniek, 5 (1988), pp. 188-208.

Jonker, J., 'The alternative road to modernity: banking and currency, 1814-1914', in M. 't Hart, J. Jonker and J. L. van Zanden, eds., A financial history of the Netherlands (Cambridge, 1997), pp. 94-123.

Kennedy, L., 'A sceptical view on the reincarnation of the Irish "Gombeenman", The Economic and Social Review, 8 (1977), pp. 213-222.

Kennedy, L., 'The early response of the Irish Catholic clergy to the co-operative movement', Irish Historical Studies, 21 (1978), pp. 55-74.

Kennedy, L., 'Traders in the Irish rural economy, 1880-1914', Economic History Review, 2nd ser., XXXII (1979), pp. 201210.

Knibbe, M., Agriculture in the Netherlands 1851-1950: production and institutional change (Amsterdam, 1993). 
Lee, J., The modernisation of Irish society (Dublin, 1973).

Lorenz, T., ed., Cooperatives in ethnic conflicts: Eastern Europe in the 19th and early 20th century (Berlin, 2006).

Maddison, A., The world economy: historical statistics (Paris, 2003).

Marck, T. H. A. M. van der, Boerenleenbanken volgens het systeem-Raiffeisen (Wassenaar, 1924).

McLaughlin, E., 'Microfinance institutions in nineteenth century Ireland' (unpub. PhD thesis, National University of Ireland, Maynooth, 2009).

McLaughlin, E., "'Profligacy in the encouragement of thrift”: savings banks in Ireland, 1817-1914', Business History (forthcoming, 2013).

Merton, R. C., ‘A functional perspective of financial intermediation', Financial Management, 10 (1995), pp. 8-21.

Merton, R. C. and Bodie, Z., 'A conceptual framework for analyzing the financial environment', in D. B. Dwight et al., eds., The global financial system: a functional perspective (Cambridge MA, 1995), pp. 3-31.

Mitchell, B. R., International historical statistics: Europe 1750-2000 (Basingstoke, 5th edn., 2003).

Moolenbel, H., Tussen plak en euro. Een overzicht van 100 jaar coöperatief bankieren in Langedijk (Heerhugowaard, 2004).

Montgomery, H. de F., 'Agricultural co-operation in Germany', Department of Agriculture and Technical Instruction for Ireland Journal, 4 (1903), pp. 214-251.

Mooij, J., 'De brandkast van het platteland: de boerenleenbanken in de jaren dertig', in W. Boonstra and J. Mooij, eds., Een eigen koers: coöperatief bankieren in turbulente tijden (Amsterdam, 2008), pp. 79-94.

Mooij, J., ed., De Rabobank van dichtbij (Utrecht, 2008).

Ó Gráda, C., Ireland: a new economic history 1780-1939 (Oxford, 1994).

Ollerenshaw, P., The Belfast banks, 1825-1914 (Manchester, 1987).

O’Rourke, K., 'The European grain invasion, 1870-1913', The Journal of Economic History, 57 (1997), pp. 775-801.

O’Rourke, K., 'Culture, conflict and cooperation: Irish dairying before the Great War', The Economic Journal, 117 (2007), pp. 1357-1379.

Pecci, V. G. R. L. (Pope Leo XIII), Rerum novarum. The rights and duties of capital and labour (Vatican, 1891).

Plunkett, H., 'Agricultural organisation', The New Ireland Review, 1 (1894), pp. 197-205.

Plunkett, H., 'Bankers and farmers in Ireland', Journal of the Institute of Bankers in Ireland, ii (1900).

Plunkett, H., Ireland in the new century (popular edn., 1905).

Rabobank Gemeente Voorst, Een eeuw vol herinneringen. 100 jaar Rabobank Gemeente Voorst 1904-2004 (Voorst, 2004).

Rommes, R., Voor en door boeren? De opkomst van het coöperatiewezen in de Nederlandse landbouw vóór de Tweede Wereldoorlog (Hilversum, forthcoming, 2013).

Russell, G. W., Co-operation and nationality (Dublin, 1912).

Sluyterman, K. E., Dankers, J. J., Linden, A. A. M. van der and Zanden, J. L. van, Het coöperatieve alternatief: honderd jaar Rabobank 1898-1998 (The Hague, 1998).

Smits, M., Boeren met beleid: honderd jaar Katholieke Nederlandse Boeren- en Tuindersbond 1896-1996 (Nijmegen, 1996). Society of St Vincent De Paul, Bulletin of the Society, XII (Dublin, 1867).

Sowers, V., 'The role of social networks in early Dutch cooperative banking: the Waspik boerenleenbank 1907-1928' (unpub. MPhil dissertation, University of Cambridge, 2011).

Stiglitz, J. E. and Weiss, A., 'Credit rationing in markets with imperfect information', The American Economic Review, 71 (1981), pp. 393-410.

Turner, J. D., “"The last acre and sixpence”: views on bank liability regimes in nineteenth-century Britain', Financial History Review, 16 (2009), pp. 111-127.

United Nations, Growth of the world's urban and rural population, 1920-2000 (New York, 1969).

Van Molle, L., 'Savings and loan guilds under the aegis of the Middenkredietkas 1892-1934', in H. van der Wee, ed., CERA 1892-1998: the power of co-operative solidarity (Bruges, 2002), pp. 13-173. 
Vaughan, W. E. and Fitzpatrick, A. J., Irish historical statistics: population, 1821-1971 (Dublin, 1978).

Vercauteren, F., Rosendaal, J. and Kuijpers, J., Boeren gingen bankieren: honderd jaar Rabobank Midden-Langstraat 19042004 (Waalwijk, 2004).

Vries, J. de, 'Visserings tijdvak 1914-1931', vol. 5, pt. 1 of Geschiedenis van De Nederlandsche Bank (Amsterdam, 1989).

Vijverberg, A., 'Het Loosduinse veilingdrama', Jaarboek Geschiedkundige Vereniging Die Haghe (2009), pp. 162-183.

Webb, S. B., 'Agricultural protection in Wilhelminian Germany: forging an empire with pork and rye', The Journal of Economic History, 42 (1982), pp. 309-326.

Weber, M., The Protestant ethic and the spirit of capitalism (1930).

West, T., Horace Plunkett: co-operation and politics, an Irish biography (Washington D.C., 1986).

Weststrate C. with Visser, T. J., Gedenkboek uitgegeven ter gelegenheid van het vijftigjarig bestaan der Coöperatieve Centrale Raiffeisen-Bank te Utrecht 1898-1948 (Utrecht, 1948).

Wolff, H. W., Peoples' banks: a record of social and economic success (1893).

Zanden, J. L. van, De economische ontwikkeling van de Nederlandse landbouw in de negentiende eeuw, 1800-1914 (Wageningen, 1985).

Zanden, J. L. van, 'The first green revolution: the growth of production and productivity in European agriculture, 18701914', Economic History Review, 2nd ser., XLIV (1991), pp. 215-239.

Zanden, J. L. van, 'Old rules, new conditions, 1914-1940', in M. 't Hart, J. Jonker and J. L. van Zanden, eds., A financial history of the Netherlands (Cambridge, 1997), pp. 124-151.

Zanden, J. L. van and Riel, A. van, The strictures of inheritance: the Dutch economy in the nineteenth century (Princeton, 2004).

\section{Official publications}

Eighth report of the Postmaster General, on the Post Office (P. P. 1862, XXVII).

Friendly and Benefit Building Societies' Commission. Reports of the assistant commissioners. Ireland, and Wales (with Monmouth and Hereford) (P.P. 1874, XXIII).

Report from the Select Committee on banks of issue; together with the proceedings of the committee, minutes of evidence, and appendix (P.P. 1875, IX).

Report from the Select Committee on industries (Ireland) (P.P. 1884-85, IX).

Agricultural statistics of Ireland, with detailed report on agriculture (P.P. 1894, CVI).

Reports from Her Majesty's representatives abroad on the Raiffeisen system of cooperative agricultural credit associations (P.P. 1895, CIII).

Report from the Select Committee on money lending (P.P. 1898, X).

Third report of the Royal Commission appointed to inquire into and report upon the operation of the Acts dealing with Congestion in Ireland (P.P. 1907, XXXV).

Report of the Chief Registrar of Friendly Societies, Workmen's Compensation Schemes, Industrial and Provident Societies, and Trades Unions (P.P. 1909, LXXIX).

Report of the Departmental Committee on agricultural credit in Ireland (P.P. 1914, XIII).

Departmental Committee on agricultural credit in Ireland: minutes of evidence, appendices and index (P.P. 1914, XIII). 
Table 1. The institutional attributes of German Raiffeisen banks and their Irish and Dutch imitations

\begin{tabular}{|c|c|c|c|}
\hline Institutional attribute & Germany & Ireland & The Netherlands \\
\hline Enterprise form & Specific cooperative form & $\begin{array}{l}\text { Choice of forms, neither designed } \\
\text { for cooperatives }\end{array}$ & $\begin{array}{l}\text { Choice of forms, varying } \\
\text { appropriateness }\end{array}$ \\
\hline Scale of operation & Local, mostly rural & Local, only rural & Local, mostly rural \\
\hline Polity coverage & National & Regional (mainly in the west) & National \\
\hline Liability structure & Unlimited & $\begin{array}{l}\text { Unlimited, regardless of enterprise } \\
\text { form }\end{array}$ & $\begin{array}{l}\text { Unlimited, regardless of enterprise } \\
\text { form }\end{array}$ \\
\hline Loan security & Cosignatories, property & Cosignatories & $\begin{array}{l}\text { Cosignatories; other collateral } \\
\text { considered }\end{array}$ \\
\hline Loan term & $\begin{array}{l}\text { Varied (short-, medium- and long- } \\
\text { term) }\end{array}$ & $\begin{array}{l}\text { Short-term only (one year } \\
\text { maximum) }\end{array}$ & $\begin{array}{l}\text { Varied (short-, medium- and long- } \\
\text { term) }\end{array}$ \\
\hline Government subsidy & $\begin{array}{l}\text { Little (some subsidized government } \\
\text { loans) }\end{array}$ & $\begin{array}{l}\text { Heavy subsidization (concessional } \\
\text { loans) }\end{array}$ & Nominal (small start-up grants) \\
\hline Use of profits & Retained & Retained & Retained \\
\hline Source of capital & Savings deposits & Government and JSB loans & Savings deposits \\
\hline Unit independence & $\begin{array}{l}\text { Yes; but influenced by apex } \\
\text { institutions }\end{array}$ & Yes & $\begin{array}{l}\text { Yes; but influenced by apex } \\
\text { institutions }\end{array}$ \\
\hline Paid management & Only treasurer is paid & None & Only treasurer is paid \\
\hline Federated apex institutions & $\begin{array}{l}\text { Separate regional clearing and audit } \\
\text { unions }\end{array}$ & None & $\begin{array}{l}\text { Combined confessional clearing and } \\
\text { audit unions (central banks) }\end{array}$ \\
\hline Cooperative integration & $\begin{array}{l}\text { Integrated with other cooperative } \\
\text { enterprises }\end{array}$ & None & $\begin{array}{l}\text { Integrated with other cooperative } \\
\text { enterprises }\end{array}$ \\
\hline
\end{tabular}

Source: Own research, based on the schema used in Hollis and Sweetman, 'Microcredit', and Guinnane, 'The early German credit cooperatives'. 
Table 2. Agricultural output per hectare in Germany, Ireland and the Netherlands

\begin{tabular}{|c|c|c|c|c|c|c|c|c|c|}
\hline & \multicolumn{3}{|c|}{ Germany } & \multicolumn{3}{|c|}{ Ireland } & \multicolumn{3}{|c|}{ The Netherlands } \\
\hline & 1871 & 1891 & 1911 & 1871 & 1891 & 1911 & 1871 & 1891 & 1911 \\
\hline Wheat & 1.17 & 1.40 & 1.98 & 1.52 & 2.15 & 2.50 & 1.65 & 1.60 & 2.63 \\
\hline Barley & 1.34 & 1.55 & 1.99 & 1.91 & 2.33 & 2.42 & 2.17 & 2.10 & 2.79 \\
\hline Oats & 1.17 & 1.53 & 1.78 & 1.59 & 1.95 & 2.04 & 1.97 & 2.01 & 2.17 \\
\hline Potatoes & 5.90 & 7.43 & 10.35 & 6.63 & 10.12 & 15.71 & 7.04 & 7.11 & 14.88 \\
\hline Sugar beet & & 24.77 & 18.84 & & & & 37.92 & 18.30 & 35.80 \\
\hline
\end{tabular}

Sources: Own calculation, using Mitchell, International historical statistics, Maddison, The world economy, and Knibbe, Agriculture in the Netherlands.

Table 3. Livestock per 1,000 of the population in Germany, Ireland and the Netherlands

\begin{tabular}{|c|c|c|c|c|c|c|c|c|c|}
\hline & \multicolumn{3}{|c|}{ Germany } & \multicolumn{3}{|c|}{ Ireland } & \multicolumn{3}{|c|}{ The Netherlands } \\
\hline & 1873 & 1892 & 1913 & 1871 & 1891 & 1911 & 1885 & 1891 & 1910 \\
\hline Horses & 90 & 78 & 71 & 100 & 127 & 141 & 74 & 59 & 55 \\
\hline Cattle & 395 & 362 & 323 & 737 & 951 & 1,076 & 415 & 334 & 339 \\
\hline Pigs & 1,774 & 251 & 395 & 300 & 292 & 325 & 122 & 119 & 211 \\
\hline Sheep & 625 & 280 & 85 & 784 & 1,009 & 892 & 213 & 177 & 149 \\
\hline Goats & 57 & 64 & 54 & & & & & & \\
\hline Poultry & & & & 2,171 & 3,264 & 5,809 & & & \\
\hline
\end{tabular}

Sources: Own calculation, using Mitchell, International historical statistics, and Maddison, The world economy. 
Table 4. The financial functions performed by German Raiffeisen banks and their Irish and Dutch imitations

\begin{tabular}{|c|c|c|c|}
\hline Financial function & Germany & Ireland & The Netherlands \\
\hline $\begin{array}{l}\text { Provides payments } \\
\text { systems to facilitate } \\
\text { economic exchange }\end{array}$ & Some & $\begin{array}{l}\text { Some, not available } \\
\text { nationally }\end{array}$ & $\begin{array}{l}\text { Some, hampered by } \\
\text { confessionalization }\end{array}$ \\
\hline $\begin{array}{l}\text { Pools funds to } \\
\text { undertake enterprise }\end{array}$ & Yes & $\begin{array}{l}\text { Very few provide } \\
\text { this function }\end{array}$ & Yes \\
\hline $\begin{array}{l}\text { Transfers economic } \\
\text { resources across time, } \\
\text { geography and } \\
\text { industry }\end{array}$ & $\begin{array}{l}\text { Across time and } \\
\text { within large } \\
\text { geographic areas }\end{array}$ & Only across time & $\begin{array}{l}\text { Across time and } \\
\text { geographies, but within } \\
\text { religious community }\end{array}$ \\
\hline $\begin{array}{l}\text { Provides ways of } \\
\text { managing uncertainty } \\
\text { and risk }\end{array}$ & Yes & $\begin{array}{l}\text { No, reliant on } \\
\text { government whim }\end{array}$ & $\begin{array}{l}\text { Yes, thanks to internal } \\
\text { savings }\end{array}$ \\
\hline $\begin{array}{l}\text { Minimises } \\
\text { information } \\
\text { asymmetries and } \\
\text { incentive problems }\end{array}$ & Yes & No & $\begin{array}{l}\text { Yes, facilitated by } \\
\text { confessionalization }\end{array}$ \\
\hline
\end{tabular}

Source: Own research, based on the schema used in Merton, 'A functional perspective'. 


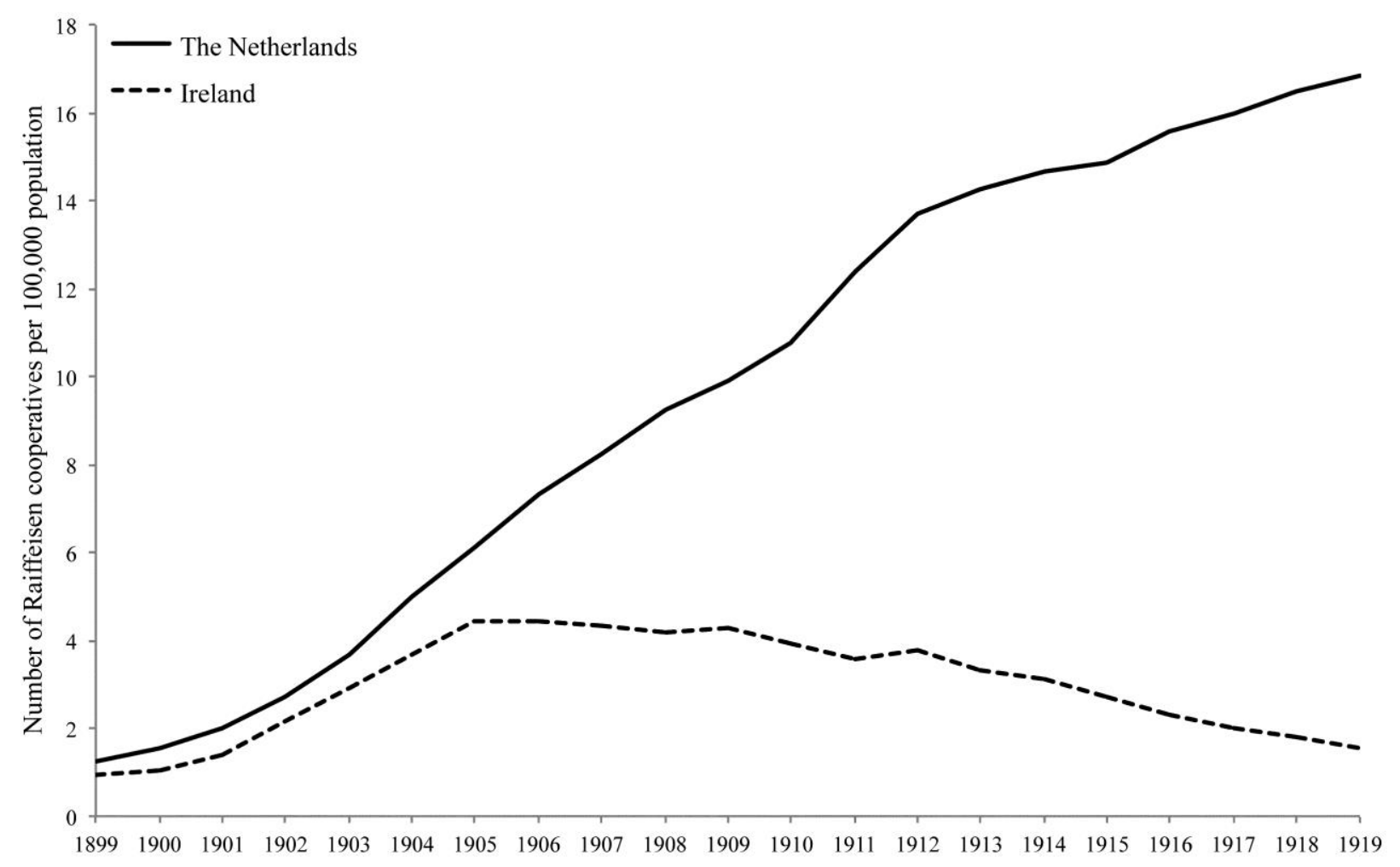

Figure 1. Number of active Raiffeisen banks in Ireland and the Netherlands per 100,000 people, 18991919

Notes: In 1919, total assets of all Raiffeisen banks to total population were $£ 0.007$ per person in Ireland and f1.20.73 (approx. £2) per person in the Netherlands.

Sources: IAOS, Annual reports 1899-1920, for the number of banks in Ireland. CCB, Jaarverslagen 1904-1919; CCCB, Jaarverslagen 1904-1919; CCRB, Jaarverslagen 1904-1919, for the number of banks in the Netherlands. Maddison, The world economy, for population estimates. 